\title{
Labor Market Effects of the World Cup: A Sectoral Analysis
}

\author{
By
}

Robert Baumann, Bryan Engelhardt, and Victor A. Matheson

May 2011

\section{COLLEGE OF THE HOLY CROSS, DEPARTMENT OF ECONOMICS FACULTY RESEARCH SERIES, PAPER NO. 11-04*}

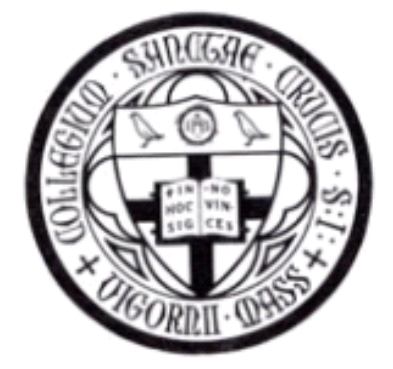

Department of Economics

College of the Holy Cross

Box 45A

Worcester, Massachusetts 01610

(508) 793-3362 (phone)

(508) 793-3708 (fax)

http://www.holycross.edu/departments/economics/website

*All papers in the Holy Cross Working Paper Series should be considered draft versions subject to future revision. Comments and suggestions are welcome. 


\title{
Labor Market Effects of the World Cup: A Sectoral Analysis
}

By

\author{
Robert Baumann ${ }^{\dagger}$ \\ College of the Holy Cross
}

\author{
Bryan Engelhardt ${ }^{\dagger \dagger}$ \\ College of the Holy Cross
}

and

Victor A. Matheson ${ }^{\dagger \dagger}$

College of the Holy Cross and Monash University

May 2011

\begin{abstract}
This paper provides an empirical examination of impact the 1994 FIFA World Cup in the United States on local employment. In contrast to ex ante economic impact reports that suggest large increases in employment due to the tournament, an ex post examination of employment in 9 host metropolitan areas finds no significant impact on employment from hosting World Cup games. Furthermore, an analysis of employment in specific sectors of the economy finds no impact from hosting games on employment in the leisure and hospitality and professional and business services sectors but a statistically significant negative impact on employment in the retail trade sector.
\end{abstract}

JEL Classification Codes: L83, O18, R53, J21

Keywords: World Cup, soccer, impact analysis, mega-event, tourism

\footnotetext{
${ }^{\dagger}$ Department of Economics, Box 192A, College of the Holy Cross, Worcester, MA 01610-2395, 508-793-3879 (phone), 508-793-3708 (fax), rbaumann@ holycross.edu

${ }^{\dagger}$ Department of Economics, Box 192A, College of the Holy Cross, Worcester, MA 01610-2395, 508-793-3879 (phone), 508-793-3708 (fax), bengelha@ holycross.edu

itt Department of Economics, Box 157A, College of the Holy Cross, Worcester, MA 01610-2395, 508-793-2649 (phone), 508-793-3708 (fax), vmatheso@ @olycross.edu
} 


\section{Introduction}

Every four years the eyes of the world's sports fans turn to the Federation International de Football Associations (FIFA) World Cup. In the run up to the 2010 World Cup, 205 national and regional teams competed in qualifying tournaments for the right to be one of the final 32 countries invited to the World Cup finals held in South Africa. Soccer's World Cup is far and away the world's largest sporting event featuring a single sport, and only the Summer Olympic Games can rival the World Cup in terms of scale and popularity. For example, the 2006 World Cup recorded an estimated 26 billion combined viewers over the course of the 64 games of the tournament and the final alone drew an estimated 715 million viewers. By comparison, the opening ceremonies of the 2008 Summer Olympics in Beijing attracted "only" 600 million viewers while the 2011 Super Bowl, the annual championship of American football, drew a record 111 million American viewers, the highest ever for an American television broadcast, but few additional non-American viewers leaving the game far behind the World Cup final's global audience (Telegraph, 2011).

The World Cup is an overwhelming financial success for FIFA itself, which funds over $85 \%$ of its operations from this quadrennial event. Between 2007 and 2010, FIFA generated $\$ 4.189$ billion in revenue with $\$ 3.655$ billion of the total coming directly from sources related to the 2010 World Cup (Australian Broadcasting Corporation, 2011). The event organizers also claim that the World Cup is an overwhelming financial success for the countries lucky enough to be awarded the event. Grant Thornton of South Africa predicted the 2010 World Cup in South Africa would have "a gross economic impact of $\$ 12$ billion to the country's economy" with 373,000 international visitors expected (Voigt, 2011). Subsequent revisions placed the economic 
impact at $\$ 7.5$ billion along with 198,400 annual jobs (Rihlamvu, 2011). Previous editions of the event elicited equally rosy predictions. The Dentsu Institute for Human Studies predicted impacts of $\$ 24.8$ billion and $\$ 8.9$ billion for Japan and South Korea, respectively, for the 1998 World Cup hosted jointly by the two countries in 2002 (Finer, 2002). During the bidding process for the 2018 World Cup, the economics practice at AECOM predicted that a World Cup based in the U.S. would generate $\$ 5$ billion for the country and generate 5,000 to 8,000 jobs in each of 12 potential host cities broadly matching the $\$ 4$ billion the firm's predecessor estimated for the previous World Cup held in 1994 in the U.S. (Slevison, 2009; Goodman and Stern 1994). The 2006 World Cup in Germany elicited estimates of between $\$ 2$ and $\$ 10$ billion in increased income along with up to 10,000 additional jobs (Feddersen and Maennig, 2010).

Of course, the expenses associated with hosting an event like the World Cup are also quite large, and the majority of the costs are typically borne by the host country. Indeed, it is only through passing along the major infrastructure costs that FIFA is able to manage to regularly amass its large surpluses. Just considering the sporting infrastructure, FIFA requires host countries to have at least 12 modern stadiums capable of seating at least 40,000 spectators with one of the stadiums being able to seat at least 80,000 for the opener and the final. Operating costs can also be quite expensive due to the extreme security measures that must be put in place. South Africa's World Cup entailed $\$ 3.9$ billion in expenses including at least $\$ 1.3$ billion in stadium construction costs (Voigt, 2010; Baade and Matheson, 2011). The 2002 World Cup required the construction of ten new stadiums in South Korea at a cost of almost $\$ 2$ billion and another 10 new or refurbished stadiums in Japan at a cost of between $\$ 4$ billion and $\$ 5.6$ billion (Sloan, 2002), while Germany followed in 2006 with 2.4 billion euros in construction costs of their own 
(Baade and Matheson, 2011). The 2018 and 2022 events in Russia and Qatar figure to be even more expensive due to the lack of existing facilities. Russian officials have stated that they are prepared to spend $\$ 10$ billion on the tournament (Rianovosti, 2009) while Qatar's bid is likely to be even more costly since it currently has only one stadium of the required size to host tournament matches. Given the enormous costs involved in hosting the tournament, it is reasonable to ask whether the predictions of economic windfall have come true in host countries.

Economists who have analyzed actual data related to the economic performance of host countries before, during, and after the World Cup have typically found identifiable benefits that are a fraction of those claimed by consultants their economic impact predictions. Using national data, Syzmanski (2002) finds that among the world's largest economies, countries hosting the World Cup over the past 30 years experienced lower economic growth during World Cup years. Sterken (2006) also examines national data and instead finds a positive but very small impact from hosting the World Cup.

Baade and Matheson (2004) were the first to undertake an ex post analysis of the economic effects of the World Cup using economic data from host cities (as opposed to countrywide data). They examine personal income growth in 13 metropolitan areas that either hosted World Cup games in the United States in 1994 or were directly adjacent to a host site. Their findings suggest that rather than a $\$ 4$ billion windfall, host cities experienced personal income growth that was below that which normally would have been predicted by a total sum of $\$ 5.5$ to $\$ 9.3$ billion. Due to the size of the economies of the metropolitan areas involved, these estimates are subject to a wide degree of variability, but sensitivity analysis performed by Baade and Matheson predicts that economic gains in the cumulative range of $\$ 4$ billion or more, as 
suggested by the consultants, can be rejected at a $1 \%$ significance level, economic gains of $\$ 500$ million or more can be rejected at a 5\% significance level, and economic gains above zero dollars can be rejected with a p-value of $6.4 \%$.

Baade and Matheson (2004), as well as other studies of mega-event analysis such as Coates and Humphreys (2002), Porter (1999), and Crompton (1995) reach similar conclusions: although measurement of changes in net spending in the local economy as opposed to gross spending should be the goal of impact analysis, economic impact predictions almost invariably measure (and publicize) gross rather than net impacts. While major events like the World Cup attract large crowds that spend significant sums of money at the games, spending by local residents typically substitutes for spending elsewhere in the local economy. This results in an increase in gross spending on the event but no increase in net economic activity for the city or country as a whole as money is simply shifting from one sector to another. Even for out of town visitors net spending is lower than gross spending to mega-events if it displaces any regular tourists to the city who would rather not arrive during a mega-event. Finally, spectator sports and mega-events tend to be associated with particularly high levels of leakages so that the economic multipliers used in impact modeling tend to be unrealistically high (Matheson, 2009; Siegfried and Zimbalist, 2002).

Other examinations of past World Cups appear to support the initial findings of Baade and Matheson (2004). Hagn and Maennig (2008) examine employment in Germany around the 1974 World Cup and find no statistically significant short- or long-term effects. Similarly, Hagn and Maennig (2009) and Feddersen, Grötzinger, and Maennig (2009) both find no short-term 
labor effects from the 2006 World Cup in Germany although neither study has an adequate amount of data following the tournament to determine any potential long-term labor benefits.

Allmers and Maennig (2009) point out that previous studies of the economic impact of the World Cup rely primarily on aggregated employment or output data. Even the impact of a large event like the World Cup can be obscured by the regular fluctuations in the large, diversified metropolitan economies in which the games are held, so Allmers and Maennig (2009) examine specific sectors of host economies for potential effects. They find no identifiable impact on overnight hotel stays, national tourism income, or retail sales in France during the World Cup in 1998 while in Germany in 2006 they find approximately 700,000 additional hotel nights sold to foreigners and an additional 600 to 700 million euros (US\$ 830 to 970 million) in net national tourism income. While these figures are substantial, they are a fraction of those claimed by event boosters.

Feddersen and Maennig (2010) examine employment in specific parts of the economy including the hospitality and construction sectors and find a statistically significant increase in employment in the hospitality sector of roughly 2,000 jobs. This is in line with ex post estimates of the sectoral employment impact of the Salt Lake City Winter Olympics in 2002 of an increase of 4,600 jobs in the leisure industry uncovered by Baumann, Engelhardt, and Matheson (2010), but a far cry from the ex ante estimates of 10,000 new jobs predicted for the German economy in 2006, the 5,000 to 8,000 jobs predicted for each of the 12 potential host cities for the failed U.S. bid for 2022, or the 198,400 new jobs estimated as a result of the 2010 South African World Cup. Feddersen and Maennig (2010) also find evidence of a decline in employment in the 
construction sector possibly as a result of the crowding out of public sector investment due to World Cup commitments.

Using a similar approach to Feddersen and Maennig (2010) and Baade, Engelhardt, and Matheson (2010), this paper utilizes sectoral employment data in host cities and sample of control cities to reexamine the effects on local economies of the 1994 World Cup in the United States. This analysis extends and improves upon the previous study of the 1994 World Cup by Baade and Matheson (2004) in several important ways. Most obviously, this paper examines employment and unemployment while the previous work looks at personal income. As noted previously, potential employment gains are often used to justify the public expenditures required to host the event.

The use of employment data has two more specific advantages over personal income or GDP data. First, employment data is available monthly, rather than quarterly or annually, for large metropolitan areas in the U.S. Identifying the economic impact of even a major event like the World Cup is akin to looking for the proverbial needle in a haystack, and the use of monthly data instead of less frequent data reduces the size of the haystack. In addition, the establishment survey provides employment data by industry type, further increasing the chances of finding the elusive "needle" as well as identifying potential winners and losers among sectors of the economy from hosting the tournament.

\section{Data and Model}

We use metropolitan statistical area employment data from the Current Employment Statistics (CES) and the Current Population Survey (CPS). The CES collects payroll data from 
businesses, and has data for overall employment as well as employment in specific industries. We use the overall employment data as well as employment in three industries: retail trade, professional and business services, and leisure and hospitality. The CPS surveys individuals and provides data on both employment and unemployment but does not have industry-specific data. Each source provides monthly data on employment for several MSAs, including all nine of the hosts of the 1994 World Cup: Chicago, Dallas, Detroit, East Rutherford, Foxborough, Orlando, Pasadena, Stanford, and Washington, D.C. Some of these locations (East Rutherford, Foxborough, Pasadena, and Stanford) are too small to have employment data, but each is part of a larger MSA that is available in the data. Appendix 1 contains further details on the MSA specification for these cities in each data set.

We use the other large MSAs (at least 500,000 employed at the beginning of the sample frame) in the data to augment the control group for the World Cup hosts. We choose 500,000 since it is the nearest round number to the smallest MSA in the sample (Orlando). This restriction leaves a total of 44 MSAs in the CES data and 39 in the CPS data, where nine are World Cup hosts. Finally, our sample frame is January, 1990 to December, 2009. The CES and CPS provide earlier employment data but not for all of the hosts of the World Cup. We present summary statistics of these data at Table 1 .

It should be noted that some MSAs designated at World Cup hosts also border other MSAs, and it is reasonable to question whether one should expand the definition of a World Cup host to include neighboring MSAs. For example, Dallas borders Forth Worth and some World Cup visitors to Dallas may have engaged in expenditures in neighboring Fort Worth. Similarly, Stanford stadium lies just within the northern border of the San Jose MSA but is less than a mile 
from the southern border of the San Francisco MSA. Most notably, Giants Stadium lies with the Bergen-Passaic MSA but most local accommodations are in next-door Newark or across the Hudson River in New York City. Indeed, Baade and Matheson (2004) include 13 MSAs rather than 9 MSAs in their World Cup host variable. This paper uses a narrower definition of World Cup host than Baade and Matheson (2004), but robustness checks on the regression results show no significant difference in outcomes if the World Cup host variable is expanded to include these additional four neighboring MSAs.

Our ex post approach is to estimate the impact on employment from hosting the World Cup. We begin with the following linear model

$$
e m p_{i t}=\beta_{0}+\theta w c_{i t}+y_{t}+m_{t}+\alpha_{i}+\varepsilon_{i t}
$$

where $e m p_{i t}$ is the employment or unemployment level of MSA $i$ in time $t . w c_{i t}$ equals one during the months an MSA hosted a World Cup game, which is either June 1994, July 1994, or both (see Appendix 1). It is plausible that the employment response is more complicated than a simple dichotomous control (see Box and Tiao, 1975), but we begin here on the assumption that if the World Cup influenced employment at all, it is most likely to have an impact during the event. This assumption is particularly bolstered by the fact that the U.S. bid, unlike more recent World Cups, exclusively utilized existing sports infrastructure. Since no facilities were newly built or significantly refurbished for the games, there is little reason to expect a large increase in employment prior to the start of the tournament. The dummy variables $y_{t}$ and $m_{t}$ are yearly- and monthly-specific controls, which absorb national trends in employment. $\alpha_{i}$ is a MSA-specific 
fixed effect that accounts for time-invariant factors of each location. Finally, $\varepsilon_{i t}$ is the overall error term.

Similar to other macroeconomic variables, several tests also suggest that the employment and unemployment levels have a unit root. Dickey-Fuller and Phillips-Perron tests on individual MSAs suggest 39 of the 44 MSAs in the CES data have a unit root at a ten percent significance level. Levin, Lin, and Chu (2002) and Im, Pesaran, and Shin (2003) tests, which are unit root tests for dynamic panel data sets such as ours, also suggest the level of employment is nonstationary. The same tests on CPS employment and unemployment provide comparable results. In response these results we transform the data using the percent change of employment (or unemployment. This transformation passes all three unit root tests above at a ten percent significance level. Another alternative is the first difference of the data, but we use percent changes here to put all of our MSAs, which have vastly different sizes, on a level playing field.

We also execute the test for autocorrelation within each panel as in Wooldridge (2002) which suggests AR terms are necessary in this model. This test estimates $\hat{\varepsilon}_{i t}=\rho \hat{\varepsilon}_{i, t-1}+u_{i t}$. If the null hypothesis of $\rho=-0.5$ is not rejected, the model likely has autocorrelation. We reject this hypothesis using employment and unemployment levels, first differences, and percent changes. Given the results of the unit root and autocorrelation tests, our model is now

$$
\% \Delta e m p_{i t}=\beta_{0}+\sum_{p=1}^{P} \delta_{p}\left(\% \Delta e m p_{i, t-p}\right)+\theta w c_{i t}+y_{t}+m_{t}+\alpha_{i}+\varepsilon_{i t}
$$

where $P$ is the number of lagged values or the autoregressive (AR) dimension of the model. We use trial-and-error to determine the optimal number of AR terms, and found that one lag is sufficient since higher-order lags are highly insignificant. 
Unfortunately, including an AR term in a fixed effects model biases the estimates. Since the use of fixed effects is equivalent to de-meaning the data by the MSA-specific means, a correlation is created between the de-meaned independent variables and the error term. Nickell (1981) demonstrates the amount of inconsistency is of order $T^{-1}$ as $N$ approaches infinity. This is a small number given we have monthly data over twenty years, although at $N=44$ we cannot assume this asymptotic figure is accurate for our model.

Kiviet (1995) proposes the estimating the amount of inconsistency and uses this result to adjust the estimates. This strategy requires estimation of two unobservable parameters: the autoregressive coefficient and the error variance. Fortunately, consistent estimates are available using the instrumental variable approaches of Anderson and Hsiao (1982), Arellano and Bond (1991), or Blundell and Bond (1998). In addition, the standard error formula in the Kiviet (1995) strategy is asymptotic, so we use a bootstrap technique based on the normal distribution from Bruno (2005). It is also plausible to estimate the model using any of the instrumental variable approaches mentioned above. We choose the Kiviet correction model based on favorable Monte Carlo comparisons (Judson and Owen, 1999; Bun and Kiviet, 2003; Bruno, 2005) and also because there is little difference in our main findings across these techniques. For comparison, we also present estimates of the AR model without the Kiviet correction. These estimations use maximum likelihood since least squares produces inconsistent estimates in AR settings. Finally, we use robust standard errors in all estimations since dynamic panels usually produce heteroskedasticity errors across MSAs.

Table 2 presents estimates from three data sets (CPS employment, CPS unemployment, and CES employment) over several econometric specifications. None of the specifications 
produce a statistically significant effect of hosting in any of the three data sets. In the CES data, the hosting effect on employment is positive in the four specifications, but the CPS data estimates a negative effect of a similar or even slightly higher magnitude is all four specifications. The CPS unemployment model provides two positive and two negative estimates. All models that include a lagged dependent variable suggest this term has explanatory power, which is not surprising given the results of our autocorrelation tests. Finally, nearly all of the yearly and monthly dummy variables are statistically significant in every specification, suggesting MSAs are sensitive to national trends.

Table 3 presents estimates from the CES sectoral data for three industries: leisure and hospitality, retail trade, and professional and business services. The only statistically significant results are in the retail trade estimations, which suggest that employment in retail trade decreased by 0.42 percentage points during the World Cup. At the average size of a World Cup host in 1994 , this translates to a loss of roughly 750 retail trade jobs per month, or 1,500 total over the two-month long event. The retail trade estimation is also unique because the lagged dependent variable term has little or no explanatory power. While testing employment in the construction sector would also be of potential interest as a comparison to Feddersen and Maennig (2010), data on construction employment were available only for a fraction of the cities in the sample (22 out of 44), so this test was not undertaken. In addition, since no stadium construction occurred in the United States as a consequence of hosting the tournament, one would not expect public investment to crowd out private construction as potentially occurred in Gernmany in 2006.

Taken together, the results suggest either zero or perhaps negative employment effects of hosting. But even at our optimistic figure, the impact of hosting is small compared to the large 
economies that hosted World Cup games in 1994. Using the largest estimate (CES Kiviet corrected lagged dependent model) at the mean employment level for World Cup hosts in 1994, the effect translates to an increase in employment of about $0.1 \%$ or roughly 1,900 jobs for each

World Cup host city per month. Since the World Cup lasted over two months for all but one city (Detroit, see Appendix), this represents an increase in employment of 3,800. However, the high standard error of this estimate produces a wide $95 \%$ confidence interval: $-12,600$ to 20,000.

Any inferences using non-statistically significant data should always be made with caution. Nevertheless, even this most optimistic point estimate of 3,800 jobs per city is less than the 5,000 to 8,000 jobs per city predicted by AECOM for the United States 2022 bid, although gains of 5,000 to 8,000 jobs cannot be rejected at normal levels of significance. Similarly, at the national average of approximately $\$ 60,000$ GDP/worker in the U.S. in 1994, the roughly 34,000 jobs across 9 cities would result in about a $\$ 2$ billion increase in national income, again roughly one-half the $\$ 4$ billion predicted. These results are also broadly in line with other studies that compare ex ante predictions with ex post reality including Allmers and Maennig (2009) and Feddersen and Maennig (2010). All told, there is no evidence in the U.S. data during the 1994 World Cup to support a claim that the event will increase employment and economic activity at the levels suggested by event promoters.

\section{Conclusions}

It is often claimed that the World Cup is a golden opportunity for a country to showcase itself to the world while also generating a substantial economic return. Ex ante estimates of the economic impact of the World Cup typically start in the billions and rise from there. The 
predictions of economic gains coincide with large predicted employment effects ranging from 10,000 new jobs well into six-figure increases. These promises of a large financial windfall prompt countries to bid vigorously to host the event and to provide substantial funding to subsidize the tournament often including billions of dollars of spending on sports related infrastructure. Do ex ante predictions match ex post reality?

Our analysis of labor markets in the U.S. during the 1994 World Cup generally finds no statistically significant change in employment or unemployment in host cities compared to cities that did not host the World Cup games. Estimates of economy-wide changes in employment in host cities, under four different estimation techniques, are all statistically insignificant, and the signs on the coefficients are as likely to suggest a fall in employment as a rise in employment. Even the most optimistic estimates suggest that the employment and income gains from the tournament were roughly one-half that claimed by the event boosters. Furthermore, an analysis of sectoral labor data shows that even in the industry most likely to be affected by the tournament, leisure and hospitality, no increase in employment can be identified. Indeed, the only industry in which the World Cup appeared to have a statistically significant impact on employment was retail trade, and in this sector of the economy the effect was negative with the presence of the tournament associated with a fall in employment of roughly 1,500 jobs per city in the sector. This result is consistent with an hypothesis that local residents substituted spending on regular retail outlets for World Cup spending and that World Cup visitors crowded out other tourists who would have been more likely to spend money on retail trade.

The results in this paper further reaffirm the conclusions of other researchers who have examined the economic impact of mega-events, and we conclude that cities should be cautioned 
from making expensive promises based on inflated predictions. From an employment standpoint, at least, the World Cup fails to live up to its billing as the world's greatest sporting event, and the excitement on the field fails to translate into jobs in local economies. 
Table 1: Summary Statistics

\begin{tabular}{|c|c|c|c|c|}
\hline & Mean & $\begin{array}{c}\text { Standard } \\
\text { Deviation }\end{array}$ & Minimum & Maximum \\
\hline World Cup Hosts & & & & \\
\hline CES employment & $1,846.80$ & $1,157.06$ & 562.9 & $4,180.4$ \\
\hline $\begin{array}{c}\text { percent change } \\
\text { CES employment }\end{array}$ & $0.055 \%$ & 1.105 & $-5.762 \%$ & $3.601 \%$ \\
\hline CPS employment & $2,472.74$ & $1,555.45$ & 624.0 & $6,235.2$ \\
\hline $\begin{array}{c}\text { percent change } \\
\text { CPS employment }\end{array}$ & $0.048 \%$ & 0.78 & $-6.492 \%$ & $2.298 \%$ \\
\hline CPS unemployment & 149.8 & 122.2 & 22.2 & 774.3 \\
\hline $\begin{array}{c}\text { percent change } \\
\text { CPS unemployment }\end{array}$ & $0.65 \%$ & 7.97 & $-30.42 \%$ & $48.78 \%$ \\
\hline Other MSAs & & & & \\
\hline CES employment & $1,108.4$ & 566.8 & 514.2 & $3,838.6$ \\
\hline $\begin{array}{c}\text { percent change CES } \\
\text { employment }\end{array}$ & $0.094 \%$ & 1.064 & $-5.108 \%$ & $2.592 \%$ \\
\hline CPS employment & $1,177.6$ & 567.9 & 504.5 & $2,865.6$ \\
\hline $\begin{array}{c}\text { percent change CPS } \\
\text { employment }\end{array}$ & $0.087 \%$ & 0.85 & $-8.097 \%$ & $5.734 \%$ \\
\hline CPS unemployment & 67.81 & 40.97 & 17.16 & 321.56 \\
\hline $\begin{array}{c}\text { percent change CPS } \\
\text { unemployment }\end{array}$ & $0.70 \%$ & 8.72 & $-33.55 \%$ & $68.23 \%$ \\
\hline
\end{tabular}

Note: All employment and unemployment numbers are in thousands. 
Table 2: Estimation Results

\begin{tabular}{|c|c|c|c|c|}
\hline & $\begin{array}{c}\text { OLS no fixed } \\
\text { effects }\end{array}$ & $\begin{array}{c}\text { OLS with fixed } \\
\text { effects }\end{array}$ & $\begin{array}{l}\text { fixed effects }- \text { no } \\
\text { Kiviet Correction } \\
(M L E)\end{array}$ & $\begin{array}{c}\text { fixed effects - } \\
\text { Kiviet Corrected }\end{array}$ \\
\hline \multicolumn{5}{|l|}{$\begin{array}{c}\text { CES } \\
\text { Employment }\end{array}$} \\
\hline $\begin{array}{c}\text { World Cup } \\
\text { host }\end{array}$ & $\begin{array}{c}0.00085 \\
(p=0.540)\end{array}$ & $\begin{array}{c}0.00109 \\
(p=0.450)\end{array}$ & $\begin{array}{c}0.00112 \\
(p=0.423)\end{array}$ & $\begin{array}{c}0.00112 \\
(p=0.650)\end{array}$ \\
\hline $\begin{array}{c}\text { lagged } \\
\text { employment }\end{array}$ & & & $\begin{array}{c}0.08261 \\
(p<0.001)\end{array}$ & $\begin{array}{c}0.08739 \\
(p<0.001)\end{array}$ \\
\hline \multicolumn{5}{|l|}{$\begin{array}{c}\text { CPS } \\
\text { Employment }\end{array}$} \\
\hline $\begin{array}{c}\text { World Cup } \\
\text { host }\end{array}$ & $\begin{array}{c}-0.00152 \\
(p=0.106)\end{array}$ & $\begin{array}{c}-0.00127 \\
(p=0.149)\end{array}$ & $\begin{array}{c}-0.00122 \\
(p=0.173)\end{array}$ & $\begin{array}{c}-0.00121 \\
(p=0.652)\end{array}$ \\
\hline $\begin{array}{c}\text { lagged } \\
\text { employment }\end{array}$ & & & $\begin{array}{c}-0.04159 \\
(p=0.005)\end{array}$ & $\begin{array}{c}-0.03763 \\
(p<0.001)\end{array}$ \\
\hline \multicolumn{5}{|l|}{$\begin{array}{c}\text { CPS } \\
\text { Unemployment }\end{array}$} \\
\hline $\begin{array}{c}\text { World Cup } \\
\text { host }\end{array}$ & $\begin{array}{c}0.00110 \\
(p=0.916)\end{array}$ & $\begin{array}{c}0.00154 \\
(p=0.812)\end{array}$ & $\begin{array}{c}-0.00107 \\
(p=0.850)\end{array}$ & $\begin{array}{c}-0.00107 \\
(p=0.967)\end{array}$ \\
\hline $\begin{array}{c}\text { lagged } \\
\text { unemployment }\end{array}$ & & & $\begin{array}{c}-0.15496 \\
(p<0.001)\end{array}$ & $\begin{array}{c}-0.15143 \\
(p<0.001)\end{array}$ \\
\hline
\end{tabular}

Note: All models include yearly and monthly dummy variables. These results are available upon request. (p-values shown in parentheses.) 
Table 3: Estimation Results for Sectoral Data

\begin{tabular}{|c|c|c|c|c|}
\hline & $\begin{array}{c}\text { OLS no fixed } \\
\text { effects }\end{array}$ & $\begin{array}{c}\text { OLS with fixed } \\
\text { effects }\end{array}$ & $\begin{array}{c}\text { fixed effects }- \text { no } \\
\text { Kiviet Correction } \\
\text { (MLE) }\end{array}$ & $\begin{array}{l}\text { fixed effects - } \\
\text { Kiviet Corrected }\end{array}$ \\
\hline \multicolumn{5}{|l|}{$\begin{array}{l}\text { Leisure \& } \\
\text { Hospitality }\end{array}$} \\
\hline $\begin{array}{c}\text { World Cup } \\
\text { host }\end{array}$ & $\begin{array}{c}-0.00254 \\
(p=0.310)\end{array}$ & $\begin{array}{c}-0.00245 \\
(p=0.446)\end{array}$ & $\begin{array}{c}-0.00158 \\
(p=0.518)\end{array}$ & $\begin{array}{c}-0.00133 \\
(p=0.428)\end{array}$ \\
\hline $\begin{array}{c}\text { lagged } \\
\text { employment }\end{array}$ & & & $\begin{array}{c}0.37142 \\
(p<0.001)\end{array}$ & $\begin{array}{c}0.37099 \\
(p<0.001)\end{array}$ \\
\hline \multicolumn{5}{|l|}{$\begin{array}{l}\text { Retail } \\
\text { Trade }\end{array}$} \\
\hline $\begin{array}{c}\text { World Cup } \\
\text { host }\end{array}$ & $\begin{array}{c}-0.00450 \\
(p=0.020)\end{array}$ & $\begin{array}{c}-0.00426 \\
(p=0.028)\end{array}$ & $\begin{array}{c}-0.00425 \\
(p=0.027)\end{array}$ & $\begin{array}{c}-0.00421 \\
(p=0.030)\end{array}$ \\
\hline $\begin{array}{c}\text { lagged } \\
\text { employment }\end{array}$ & & & $\begin{array}{c}0.00768 \\
(p=0.473)\end{array}$ & $\begin{array}{c}0.00673 \\
(p=0.567)\end{array}$ \\
\hline \multicolumn{5}{|l|}{$\begin{array}{l}\text { Professional \& } \\
\text { Business Serv. }\end{array}$} \\
\hline $\begin{array}{c}\text { World Cup } \\
\text { host }\end{array}$ & $\begin{array}{c}0.00055 \\
(p=0.869)\end{array}$ & $\begin{array}{c}0.00071 \\
(p=0.850)\end{array}$ & $\begin{array}{c}0.00084 \\
(p=0.803)\end{array}$ & $\begin{array}{c}0.00085 \\
(p=0.817)\end{array}$ \\
\hline $\begin{array}{c}\text { lagged } \\
\text { unemployment }\end{array}$ & & & $\begin{array}{c}0.05594 \\
(p<0.001)\end{array}$ & $\begin{array}{c}0.05529 \\
(p<0.001)\end{array}$ \\
\hline
\end{tabular}

Note: All models include yearly and monthly dummy variables. These results are available upon request. (p-values shown in parentheses.) 


\section{References}

Allmers, S., and W. Maennig, W. (2009). "Economic Impacts of the FIFA Soccer World Cups in France 1998, Germany 2006, and Outlook for South Africa 2010,” Eastern Economic Journal, Vol. 35:4, 500-519.

Anderson, T.W. and C. Hsiao (1981). "Formulation and Estimation of Dynamic Models Using Panel Data," Journal of Econometrics, Vol. 18, 570-606.

Arellano, M. and S.R. Bond. (1991). "Some Tests of Specification for Panel Data: Monte Carlo Evidence and an Application to Employment Equations," Review of Economic Studies, Vol. 58, 277-297.

Australian Broadcasting Corporation (2011). "2010 World Cup 'a huge financial success'," http://www.abc.net.au/news/stories/2011/03/03/3154951.htm, accessed March 31, 2011, posted March 4, 2011.

Baade, R. and V. Matheson (2004). "The Quest for the Cup: Assessing the Economic Impact of the World Cup," Regional Studies, Vol. 38:4, 343-354.

Baade, R. and V. Matheson (2011). "Financing Professional Sports Facilities," Financing for Local Economic Development, $2^{\text {nd }}$ ed., Zenia Kotval and Sammis White, eds., (NewYork: M.E. Sharpe Publishers, forthcoming).

Baumann, R., B. Engelhardt, and V. Matheson (2010). "Employment Effects of the 2002 Winter Olympics in Salt Lake City, Utah," College of the Holy Cross, Department of Economics, Working Paper Series, No. 10-02.

Blundell, R. and S. Bond (1998). "Initial Conditions and Moment Restrictions in Dynamic Panel Data Models," Journal of Econometrics, 87, 115-143. 
Box, G. and G. Tiao (1975). "Intervention Analysis with Applications to Economic and Environmental Problems," Journal of the American Statistical Association, Vol. 70, 7079.

Bun, M. and J. Kiviet (2003). "On the diminishing returns of higher-order terms in asymptotic expansions of bias," Economics Letters, 79:2, 145-152.

Bruno, G. (2005). "Estimation, inference and Monte Carlo analysis in dynamic panel data models with a small number of individuals" Stata Journal, 5:4, 473-500.

Coates, D. and B. Humphreys (2002). “The Economic Impact of Post-Season Play in Professional Sports," Journal of Sports Economics, Vol. 3:3, 291-299.

Crompton, J. (1995). "Economic impact analysis of sports facilities and events: eleven sources of misapplication," Journal of Sport Management, Vol. 9:1, 14-35.

Feddersen, A., A.L. Grötzinger, and W. Maennig, (2009). "Investment in Stadia and Regional Economic Development - Evidence from FIFA World Cup 2006,” International Journal of Sport Finance, Vol. 4:4, 221-239.

Feddersen, A. and W. Maennig, (2010). "Sectoral Labour Market Effects of the 2006 FIFA World Cup," Hamburg Contemporary Economic Discussions, No. 33.

Finer, J. (2002). “The Grand Illusion,” Far Eastern Economic Review, March 7, 2002, 32-36.

Goodman, R. and R. Stern (1994). "Chicago hosts opening game of World Cup,” Illinois Parks and Recreation, Vol. 25:3.

Hagn, F. and W. Maennig (2008). "Employment effects of the Football World Cup 1974 in Germany," Labour Economics, Vol. 15:5, 1062-1075. 
Hagn, F. and Maennig, W. (2009). "Labour Market Effects of the 2006 Soccer World Cup in Germany," Applied Economics, Vol. 41:25, 3295-3302.

Im, K.S., Pesaran, M.H., and Shin, Y. (2003). Testing for unit roots in heterogeneous panels. Journal of Econometrics 115 (1), 53-74.

Judson, K.A. and A.L. Owen (1999). “Estimating Dynamic Panel Data Models: A Guide for Macroeconomists," Economics Letters, Vol. 65, 9-15.

Kiviet, J.F. (1995). “On Bias, Inconsistency, and Efficiency of Various Estimators in Dynamic Panel Models," Journal of Econometrics, Vol. 68, 53-78.

Levin, A., C.F. Lin and C.S.J. Chu (2002). "Unit Root Tests in Panel Data: Asymptotic and Finite-Sample Properties," Journal of Econometrics, Vol. 108, 1-24.

Matheson, V. (2009). “Economic Multipliers and Mega-Event Analysis,” International Journal of Sport Finance, Vol. 4:1, 63-70.

Nickell, S. (1981). "Biases in Dynamic Models with Fixed Effects," Econometrica, Vol. 49, 1417-26.

Porter, P.K. (1999). “Mega-Sports Events as Municipal Investments: A Critique of Impact Analysis," in J. Fizel, E. Gustafson, \& L. Hadley, eds., Sports Economics: Current Research, (Westport, CT: Praeger Publishers), 61-74.

Rianovosti (2009). "Putin orders sports minister to prepare bid for 2018 World Cup," http://en.rian.ru/sports/20090505/121448011.html, accessed March 31, 2011, posted May $5,2009$.

Rihlamvu, Edwin (2011). “2010 FIFA Soccer World Cup,” Africa Travel, http://www.africaata.org/sports.htm, accessed March 31, 2011. 
Siegfried, J. and A. Zimbalist (2002). "A Note on the Local Economic Impact of Sports Expenditures," Journal of Sports Economics, Vol. 3:4, 361-366.

Slevison, Andrew (2009). "\$5 billion economic impact if World Cup hits U.S. shores," TribalFootball.com, accessed March 31, 2011, posted October 30, 2009.

Sloan, D. (2002). “Cup Offers Japan Economic Free Kick,” XtraMSN, http://xtramsa.co.nz/sport/0,,3951-1071885,00.html, posted 1/25/2002, accessed $2 / 20 / 2002$.

Sterken, E. (2006). “Growth Impact of Major Sporting Events," European Sport Management Quarterly, Vol. 6:4, 375-389.

Szymanski, S. (2002). "The Economic Impact of the World Cup," World Economics, 3:1, 169177.

Telegraph, The (2011). "Super Bowl set U.S. TV record audience," http://www.telegraph.co.uk/sport/othersports/americanfootball/8310107/Super-Bowl-setUS-TV-record-audience.html, accessed March 31, 2011, posted February 8, 2011.

Voigt, Kevin (2010). "Is there a World Cup economic bounce?” CNN.com, http://edition.cnn.com/2010/BUSINESS/06/11/business.bounce.world.cup/index.html, accessed March 31, 2011, posted June 11, 2010.

Wooldridge, J. (2002). Introductory Econometrics: A Modern Approach, 2nd ed. (New York: South-Western College Publishers). 


\section{Appendix}

1. In the cases of World Cup hosts that are too small to have MSA data in the CES or CPS, we use the following MSAs for each city:

\begin{tabular}{|c|c|c|}
\hline City & CES MSA & CPS MSA \\
\hline East Rutherford, NJ & Bergen-Hudson-Passaic, NJ & Newark-Union, NJ-PA \\
\hline Foxborough, MA & $\begin{array}{c}\text { Boston-Cambridge-Quincy, } \\
\text { MA-NH }\end{array}$ & $\begin{array}{c}\text { Boston-Cambridge-Quincy, } \\
\text { MA-NH }\end{array}$ \\
\hline Pasadena, CA & Los Angeles-Long Beach- & $\begin{array}{c}\text { Los Angeles-Long Beach- } \\
\text { Santa Ana, CA }\end{array}$ \\
\hline Stanford, CA & Glendale, CA & San Jose-Sunnyvale-Santa \\
& Clara, CA & Clara, CA \\
\hline
\end{tabular}

In general, we use the smallest MSA possible that contains each city in order to produce the best possible chance of identifying employment effects of the World Cup. Choosing larger MSAs, say the New York City metropolitan area for East Rutherford, produced no substantial changes in the results.

2. World Cup games were hosted in June and July 1994 with one exception: Detroit only hosted in June 1994. 